\title{
MOLECULAR IDENTIFICATION OF COTTON WHITEFLY BEMISIA TABACI GENN. (HEMIPTERA: ALEYRODIDAE) POPULATIONS OF TURKEY BASED ON MITOCHONDRIAL CYTOCHROME OXIDASE SUBUNIT I
}

\author{
DAĞLI, F. ${ }^{1 *}$ - YÜKSELBABA, U. ${ }^{1}$ - İKTEN, C. ${ }^{1}$ - TOPAKÇI, N. ${ }^{2}$ - GÖÇMEN, H. ${ }^{1,3}$ \\ ${ }^{I}$ Department of Plant Protection, Faculty of Agriculture, Akdeniz University, 07059 Antalya, \\ Turkey \\ ${ }^{2}$ Vocational School of Technical Science, Akdeniz University, 07059 Antalya, Turkey \\ ${ }^{3}$ Department of Plant Protection, Faculty of Agriculture, Kyrgyz-Turkish Manas University, \\ 720044 Bishkek, Kyrgyzstan \\ *Corresponding author \\ e-mail:fdagli@akdeniz.edu.tr; phone: +90-242-310-2426; fax: +90-242-310-2479
}

(Received $31^{\text {st }}$ Oct 2019; accepted $30^{\text {th }}$ Jan 2020)

\begin{abstract}
The cotton whitefly (Bemisia tabaci Genn.) is a major pest of cultivated plants in tropical and subtropical regions. In this study, the genetic diversity between populations and various biotypes of $B$. tabaci collected from Hatay, Adana, İçel, Antalya, Muğla, Aydın and Denizli provinces of Turkey were investigated using mitochondrial cytochrome oxidase subunit 1 (mtCOI) sequences. Thirty-two nucleotide variations were found in a $617 \mathrm{bp}$ mtCOI sequence of the among the populations studied. Phylogenetic analysis divided the $B$. tabaci populations of Turkey into two groups clustering around the main Middle East-Asia Minor 1(MEAM1) and Mediterranean (MED) groups, (i.e. the so-called B and Q biotypes respectively). Mediterranean species were also divided into two subgroups. The populations from Aydin and Denizli provinces identified as the Qw haplotype were closely related to populations of Greece, whereas the remaining samples were identified as the Qe haplotype. This study indicated that the biotype status of the $B$. tabaci populations might have changed from year to year depending on several factors, such as insecticide resistance, host plant preferences, and climate niches to understand the factors causing changes in the biotype structure, pest populations should be monitored, and surveys must be conducted at regular intervals.
\end{abstract}

Keywords: whitefly, biotype, MEAM1, Mediterranean, genetic variability

\section{Introduction}

Bemisia tabaci (Genn.) is one of the most important pests of industrial plants, vegetables and cotton in tropical and subtropical regions (Brown et al., 1995). The pest was initially identified in Greece in 1889, and it has been responsible for several outbreaks in cotton. Although, its history dates back to 1928, the exact timeframe over which B. tabaci has caused damage to plants cultivated in Turkey is unknown (Göçmen and Özgür, 1990).

Bemisia tabaci has been reported to contain various biotypes that are morphologically indistinguishable from each other but differ according to their host sequences, fecundity, insecticide resistance and virus carrying ability (Bedford et al., 1994). Studies have shown that these biotypes can be genetically distinguished from each other using molecular methods (Frohlich et al., 1999; Bedford et al., 1994; Costa and Brown, 1991). 
In terms of qualitative and quantitative characteristics, the B. tabaci biotypes have been differentiated based on protein (Costa and Brown, 1991; Brown et al., 1995) and nucleotide polymorphisms using random amplified polymorphic DNA (RAPD) markers (Gawell and Barlett, 1993; Lima et al., 2002; Moya et al., 2001), amplified fragment length polymorphism (AFLP) markers (Cervera et al., 2000), restriction fragment length polymorphism (RFLP) markers (Abdullahi et al., 2004), ribosomal ITS1 sequences (De Barro, 2000) and microsatellites (De Barro, 2005; Valle et al., 2013). Furthermore, biotypes can be separated by analysing gene sequences isolated from the mitochondrial DNA (mtDNA) (Frohlich et al., 1999). Currently, because of the limitations of some molecular techniques, mtCOI gene is proposed for identification of several species within the B. tabaci complex (Dinsdale et al., 2010). Hitherto, B. tabaci has been reported to form a complex comprised of at least 24 different species that cannot be separated morphologically from each other (Dinsdale et al., 2010; De Barro et al., 2011).

The diversity of $B$. tabaci biotypes in Turkey has been investigated before. Bedford et al. (1994) reported the $B$. tabaci populations as the M biotype. Göçmen and Devran (2002) studied the genetic structures of eight $B$. tabaci populations collected from Antalya with the AFLP technique and found 2 groups in relation to their hosts. Ulusoy et al. (2002) reported the presence of the B biotype in the B. tabaci populations in Turkey. Göçmen et al. (2004) also predicted that the B, Q and M biotypes were found in Turkey using RAPD markers. In another study Bayhan et al. (2006) reported that the B. tabaci populations collected from Adana, Mersin and Hatay provinces were the B biotype based on analysis of the same single gene region for all the mtCOI sequences. Karut et al. (2012) carried out a survey on pests collected from cucumber, cotton, eggplant and soybean in the 2008-2009 production seasons in the Balcall district of Adana and reported that the $B$. tabaci populations belonged to the $\mathrm{B}$ and $\mathrm{Q}$ biotypes, with the $\mathrm{Q}$ biotype being the most dominant. In 2015, southwestern populations of B. tabaci collected from cotton fields were also studied (Karut et al., 2017). According to the above findings, to date studies have been restricted to the eastern provinces of Turkey, and there is a need to determine the distribution of whitefly biotypes in Turkey using mtCOI sequences.

In this study, B. tabaci populations were sampled from various cultivated plants during 2005 and 2006 from different provinces of Turkey and identified as biotypes based on the sequence analysis of mtCOI regions. The purpose of the study was to determine the species/biotype structure and genetic diversity of the $B$. tabaci populations in Turkey. Furthermore, phylogenetic analysis was conducted to clarify the relationships among $B$. tabaci populations in Turkey.

\section{Materials and methods}

Adult B. tabaci samples were collected from cultivated plants in the Hatay, Adana, İçel, Antalya, Muğla, Aydın and Denizli provinces of Turkey (Table 1; Fig. 1). At least 100 individual adults were collected from each location using a mouth aspirator and stored in $96 \%$ alcohol for DNA isolation.

\section{DNA extraction}

Total DNA was isolated from the $B$. tabaci adults by using Omega DNA isolation kit (EZNA SQ Tissue DNA Kit, D5040-02) according to the manufacturer's instructions. The DNA was precipitated in isopropanol, kept at $20{ }^{\circ} \mathrm{C}$ overnight and then dissolved in $30 \mu 1$ of distilled water. 
To identify the biotypes of the collected whitefly samples, a combination of the C1J-2195(Primer A) and L2-N-3014 (Primer B) primer sets designed by Frohlich et al. (1999) was used to amplify a fragment of the mtCOI gene region (Table 2).

Table 1. Sampling locations and host plants of the Bemisia tabaci

\begin{tabular}{|c|c|c|c|}
\hline Location & Host & Sampling date & GenBank accession numbers \\
\hline \multicolumn{4}{|l|}{ HATAY } \\
\hline Kırıkhan-Hassa & Cucumber & 03.09 .2005 & MK360004 \\
\hline Samandağ & Eggplant & 03.09 .2005 & MK360005 \\
\hline \multicolumn{4}{|l|}{ ADANA } \\
\hline Mihmandar & Cotton and soybean & 02.09 .2005 & MK360006 \\
\hline Mustafabeyli & Cucumber & 02.09 .2005 & MK360007 \\
\hline \multicolumn{4}{|l|}{ MERSIN (İÇEL) } \\
\hline Mahmutağa (Tarsus) & Eggplant & 04.09 .2005 & MK360008 \\
\hline Gümüşkum & Eggplant & 04.09 .2005 & MK360009 \\
\hline Ovacık (Silifke) & Eggplant & 04.09 .2005 & MK360010 \\
\hline Melleç (Anamur) & Nightshade & 01.09 .2005 & MK360011 \\
\hline \multicolumn{4}{|l|}{ ANTALYA } \\
\hline Yurtpınar (Aksu) & Eggplant & 30.09 .2005 & MK360012 \\
\hline Kampus (Uncal1-city center) & Cotton & 28.11 .2005 & MK360013 \\
\hline Konaklı (Alanya) & Eggplant & 30.09 .2005 & MK360014 \\
\hline Çobanlı (Gazipaşa) & Cucumber & 30.09 .2005 & MK360015 \\
\hline Demirtaş (Alanya) & Eggplant & 30.09 .2005 & MK360016 \\
\hline Kumluca (Mavikent) & Pepper & 05.07 .2006 & MK360017 \\
\hline Demre & Pepper & 05.07 .2006 & MK360018 \\
\hline \multicolumn{4}{|l|}{ MUĞLA } \\
\hline Kınık & Cotton & 17.08 .2006 & MK360019 \\
\hline Fethiye-Çalış & Eggplant & 18.08.2006 & MK360020 \\
\hline Ortaca & Cucumber & 18.08 .2006 & MK360021 \\
\hline \multicolumn{4}{|l|}{ AYDIN } \\
\hline Koçarlı & Cotton & 18.08 .2006 & MK360022 \\
\hline \multicolumn{4}{|l|}{ DENIZLLI } \\
\hline Beylerbeyi & Cotton & 19.08 .2006 & MK360023 \\
\hline
\end{tabular}

Table 2. Primer sequences used in the amplification of the mtCOI gene region (Frohlich et al., 1999)

\begin{tabular}{c|c|c}
\hline Primer name & Primer sequence & Fragment size (bp) \\
\hline Primer A (Forward) & 5' TTGATTTTTTGGTCATCCAGAAGT 3' & $\sim 800 \mathrm{bp}$ \\
Primer B (Reverse) & 5' TCCAATGCACTAATCTGCCATATTA 3' & ------- \\
Primer C (Forward) & 5'ATAGCAGTGAGGCTGGAAAA 3' & $760 \mathrm{bp}$ \\
Primer D (Forward) & 5' GGGTATAATTTATGCTATA 3' & $720 \mathrm{bp}$ \\
\hline
\end{tabular}

Each PCR reaction was performed in a total volume of $12.5 \mu$ containing $0.2 \mathrm{mM}$ dNTPs (Larova), $2.5 \mathrm{mM}$ of each primer (Biomer), 0.5 units of Taq DNA Polymerase 
(Bioron), $1.25 \mu \mathrm{l}$ of reaction buffer solution, $4 \mathrm{mM} \mathrm{MgCl} 2$ and $1 \mu 1$ of DNA, as described by Frohlich et al. (1999).

Polymerase chain reaction (PCR) was carried out using the following cycling parameters: an initial denaturation step at $94{ }^{\circ} \mathrm{C}$ for $2 \mathrm{~min}$, and 30 cycles of a denaturation step at $94{ }^{\circ} \mathrm{C}$ for $45 \mathrm{~s}$, an annealing step at $48{ }^{\circ} \mathrm{C}$ for $45 \mathrm{~s}$ and an extension step at $72{ }^{\circ} \mathrm{C} 45 \mathrm{~s}$. The amplified products were separated and visualized on a $1 \%$ agarose gel containing $10 \mathrm{mg} / \mathrm{l}$ of ethidium-bromide. Amplification products of approximately $800 \mathrm{bp}$ in length were re-amplified with the primers $\mathrm{B}$ and $\mathrm{C}$ (Table 2) using the same PCR conditions used for the nested PCR amplifications when the amplicon yield was not sufficient for direct Sanger sequencing of the initial PCR products.

Single-band PCR products with the expected fragment size (760 bp) were stored at $20{ }^{\circ} \mathrm{C}$ for sequencing. Three different PCR products derived from different individuals from each population were sequenced with the $\mathrm{B}$ and $\mathrm{Q}$ biotype control samples obtained from Dr. A. R. Horowitz.

The amplicons were subjected to DNA sequencing using the capillary Sanger sequencing platform and the Beckman 8000 CEQ Genetic Analysis System according to the manufacturer's instructions with the exception of the reaction volume which was $10 \mu \mathrm{l}$ instead of $20 \mu \mathrm{l}$. Since better and clear electropherogram signals were obtained from the forward primer $\mathrm{D}$ than for forward primer $\mathrm{C}$ in the initial tests, the sequencing reactions were carried out in both directions using forward primer $\mathrm{D}$ and reverse primer $\mathrm{B}$.

\section{Phylogenetic analysis}

The raw fluorescence data were analysed with the 'Beckman Sequence Analysis' program. The obtained sequences were manually confirmed and edited, and the sequence of each individual sample was finalized. The determination of biotype structure of the cotton whitefly populations in Turkey and phylogenetic analyses were conducted as outlined in Boykin and De Barro (2014) with curated global dataset of mtCOI sequences of Bemisia tabaci species (Boykin et al., 2017). The sequences were aligned using Clustal W implemented in the MEGAX software (Kumar et al., 2018), and the phylogenetic analysis was performed using the MEGA $X$ program with the Kimura two-parameter model and Neighbor- Joining method with 1000 bootstrap iterations. The genetic distances were calculated using Maximum Composite Likelihood Option of MEGAX.

\section{Results}

All whitefly samples yielded a band with an expected fragment size of $~ 760 \mathrm{bp}$ using the indicated primer pair (Table 2) to amplify the mtCOI fragment. The sequences were trimmed to a length of $617 \mathrm{bp}$ and aligned with the CLUSTAL W program. The alignment results indicated a lack of variation among samples derived from the same populations. Samples from the same population were identified as having the same mtCOI sequences (single haplotype) and therefore were considered as homogeneous.

In contrast to the lack of variation within populations, a total of thirty-two nucleotides variants were detected in the $617 \mathrm{bp}$ sequence of the analysed region among populations. All of the variable nucleotide positions involved a single base substitution with the exception of one position at which the B, Qw and Qe haplotypes had the T, A, 
and $\mathrm{C}$ nucleotides, respectively. Furthermore, nucleotide bases in variable positions were not independent of each other. In other words, the nature of the variation at any nucleotide position in the mtCOI gene was related to the structure of the other changes. Therefore, the thirty-two different nucleotide polymorphisms identified in the studied populations did not result in thirty- two different haplotypes. Indeed, only three different haplotype groups were present in all tested individuals (Fig. 1). Among all haplotypes, the average nucleotide frequencies were $\mathrm{A}=0.255, \mathrm{~T}=0.431, \mathrm{G}=0.185$ and $\mathrm{C}=0.128$. Hence, in light of these nucleotide values, the $\mathrm{T}+\mathrm{A}$ and $\mathrm{C}+\mathrm{G}$ base ratios reflected the rich $\mathrm{A}+\mathrm{T}$ composition typically found in the genes of insect mitochondrial genes.

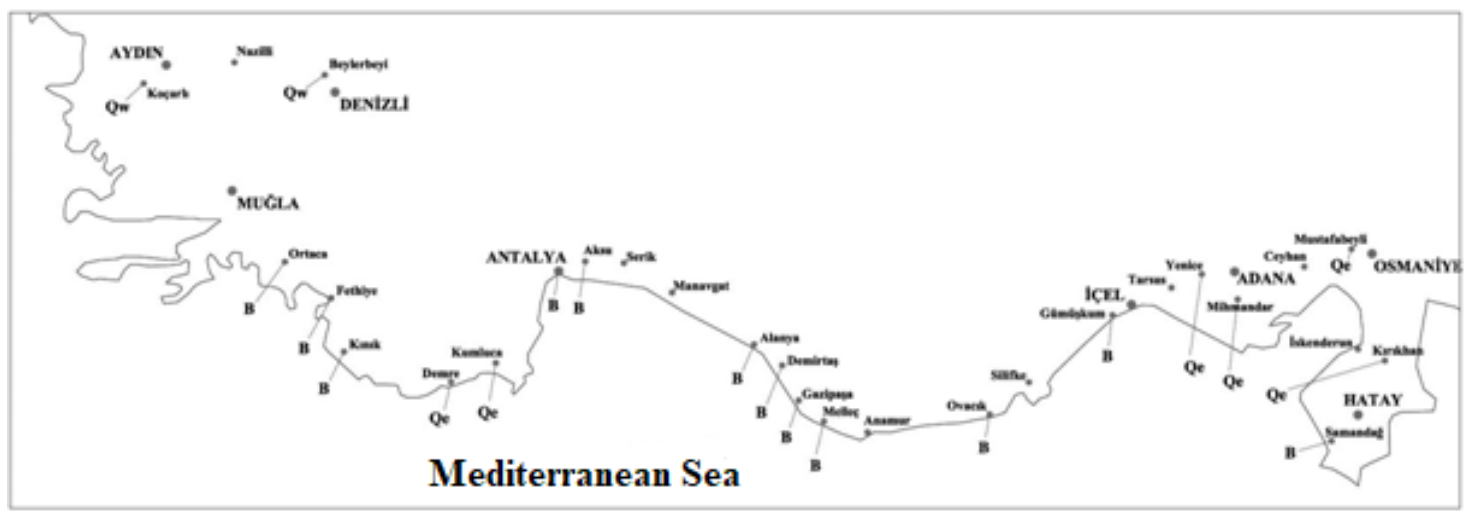

Figure 1. The geographical distribution of the Bemisia tabaci biotypes in Turkey

The Neighbor- Joining phylogenetic tree demonstrated that the cotton whitefly populations from Turkey were grouped into three different clusters (Fig. 2). When these populations were examined in relation to curated global dataset, they were grouped into two different biotypes commonly known worldwide as the B and Q biotypes which belong to the Middle East-Asia Minor 1 and Mediterranean species, respectively. Of the 20 populations analyzed eleven clustered with the B biotype in the same haplotype group (Fig. 2). Although the remaining nine populations were clustered with the $\mathrm{Q}$ biotype, the two populations collected from the Aydın-Denizli provinces (western Turkey) slightly differed from the other 7 population having Q biotype (Fig. 2). These two Q haplotypes were categorized with those present in Syria and Cyprus under the newly designated Qe haplotype, and the others were clustered with those present in Greece and Turkey/Aydin and Denizli province under the Qw haplotype to clearly delineate them (Fig. 2).

When the genetic distances of the three clusters of the Turkish populations were analyzed, they were observed to be less related to the other main group because they clustered under the main Mediterranean and MEAM1 group (Fig. 2). Accordingly, while the distance between the reference B biotype and Qe was 0.050, its distance to Qw was 0.055 and the genetic distance between Qe and Qw haplotypes was only 0.010. In contrast, the distances of the Turkish populations to the other world biotypes varied between 0.231 and 0.252 (Fig. 2). No nucleotide polymorphism was identified among all 11 Turkish populations of the B biotype. Similarly, no nucleotide polymorphism was found among the seven Qe haplotype populations or between the two Qw haplotype populations. 


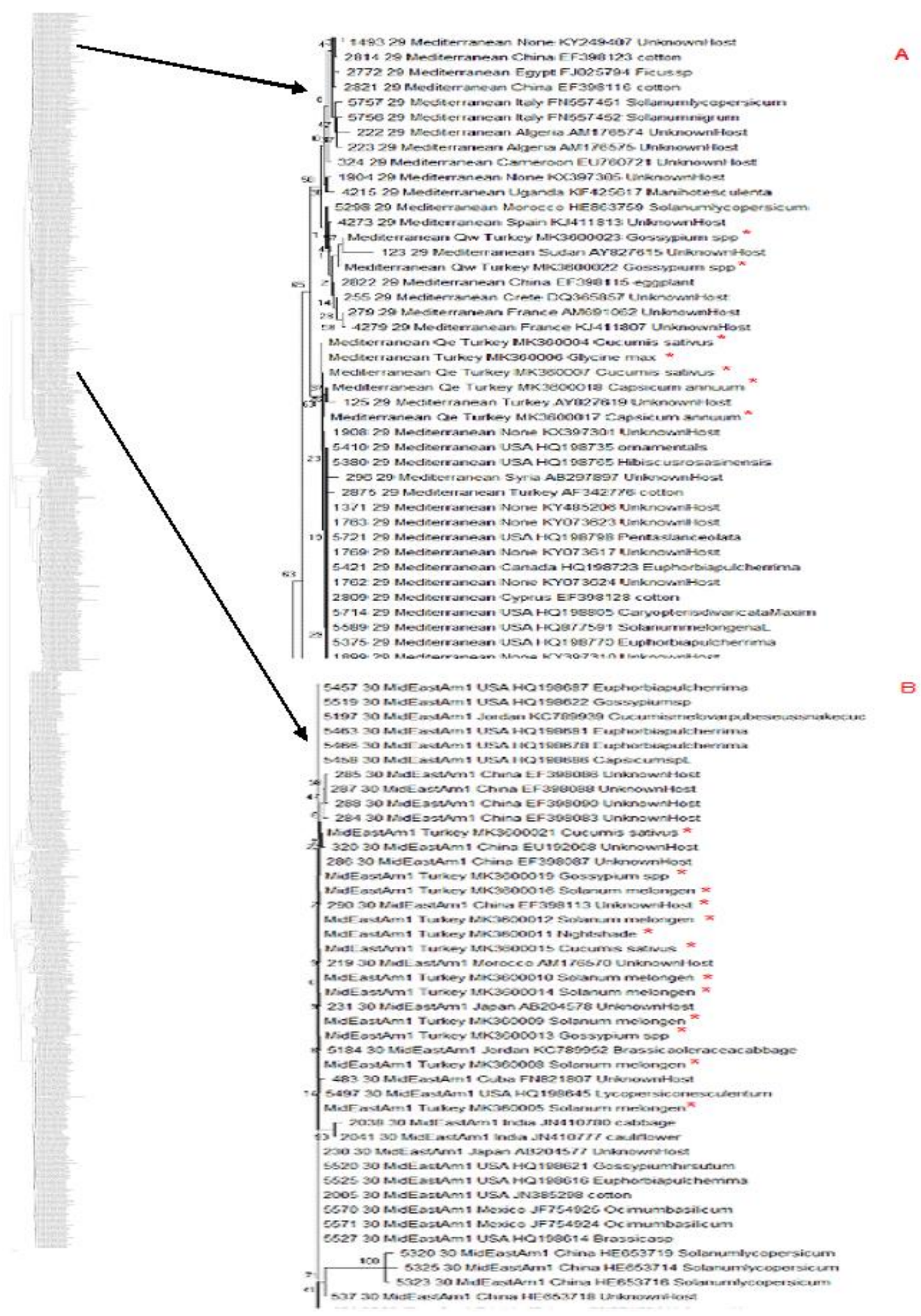

Figure 2. Two parts of the phylogenetic tree generated by the MEGAX Phylogenetic Analysis Program under the Neigbour Joining with 1000 Bootstrap values using the mtCOI sequences of the curated global dataset and cotton whitefly samples collected from different geographical regions of Turkey. A: whitefly samples from Turkey clustered within Mediterranean species, B: whitefly samples from Turkey clustered within MEAM1 species (complete tree was added as supplementary file). *Populations used in this study 


\section{Discussion}

The mtCOI gene region sequence was first used by Frohlich et al. (1999) to determine the biotypes of whitefly populations from different parts of the world. They were identified about 240 polymorphic nucleotides in their study. However, in our study, only 32 polymorphic nucleotides were detected. Similarly, Horowitz et al. (2003) reported limited polymorphism levels in populations collected from narrow geographical regions like our findings. Although the polymorphism level recorded in this study was low compared to that of the global populations, the mtCOI sequence information both provided sufficient data about the cotton whitefly populations in Turkey and allowed us to determine the biotypes in different regions of the country. When the geographical distribution of these biotypes was analysed, the emergence of the certain biotypes was observed intermittently rather than in a structure of spread and infestation into a geographical region. For instance, whereas the B biotype was prevalent in the Hatay/Samandağ 1 region, the Q biotype was found in the Kirıkhan region (Fig. 1). Similarly, whereas the B biotype was present in the eastern region of Antalya, the Q biotype was found in the western region of the province; moreover, the B biotype was observed as the dominant population in Muğla province, which is geographically close to Antalya (Fig. 1).

In the current study, investigation of the biotype distribution in Turkey found that the B biotype was intermittently present in three geographical regions. The biotype could either have been introduced into Turkey from various locations and thus was still been undergoing the spreading process or could have been introduced into Turkey from only one location and not yet replaced the $\mathrm{Q}$ biotype in some regions. Another scenario was that the B biotype became the prevalent biotype after its introduction into Turkey, but the $\mathrm{Q}$ biotype started to dominate the B biotype in various geographical regions, as was observed recently. For instance, the Q biotype was identified several years after the B biotype was identified in Spain (Guirao et al., 1997). Later the Q biotype prevailed in some regions, whereas the B and Q biotypes survived together in others (Simón et al., 1999). In surveys conducted in these regions, only the Q biotype was detected (Simón et al., 2007).

In a study conducted between 2000 and 2002 in the Adana, Mersin and Hatay provinces of Turkey, the B biotype was the sole biotype present in these regions. Additionally, nucleotide polymorphisms were reported to be at a very low level among the B biotype populations which were highly homogeneous (Bayhan et al., 2006). The homogeneity of the B biotype reported by Bayhan et al. (2006) was in accordance with our findings because all populations in this study were clustered around the B biotype with $100 \%$ nucleotide sequence similarity. Since the GenBank accession numbers of the B biotypes reported by Bayhan et al. (2006) were not provided, we could not make a direct comparison between those sequences and the sequences generated in this study. The B biotype was also identified in Mersin province in 2004 (Topakçı and Göçmen, 2018). In another study carried out in the Mersin and Antakya provinces, whitefly samples collected from cucumbers, beans and tomatoes between 2007 and 2009, were identified as the B biotype (Erdoğan et al., 2011). These two studies clearly proved that the $\mathrm{B}$ biotype was the dominant biotype in these provinces.

In 1985, the whitefly specimens collected from cotton plants in Adana were named ' $\mathrm{TC}$ ' and were reported to present very similar mtCOI nucleotide profiles to the $\mathrm{Q}$ biotype (Bedford et al., 1994). The Q biotype was determined to be rife in our study among samples collected from the Adana and Hatay regions. In this region, the presence 
of the Q biotype in the 2004 samples came to the forefront. (Topakç1 and Göçmen, 2018). In addition, we have observed that this trend to continued based on samplings from among the regions. Also Karut et al. (2012) reported in their study performed in Adana that four of the 18 samples collected from cucumbers, cotton, eggplants and soya in 2008 and in only one of the 13 samples collected from the same plant species in 2009 were identified as be the B biotype; hence, the remaining samples were the Q biotype. During the 2006-2011 (except for the 2010) period, the majority of the whitefly population collected from cotton plants in Adana were identified as the Q biotype within the Mediterranean group (Karut et al., 2014).

Based on the above findings, the Q biotype may have been the local biotype in the past and then lost its dominance due to an aggressive $\mathrm{B}$ biotype within the region. In reference to Bayhan et al. (2006) we can speculate that the B biotype was dominant in the region and continues to spread. However, this trend has changed after 2005, when the Q biotype has started to replace the B biotype in Adana and Hatay provinces. As demonstrated in this study, the $\mathrm{Q}$ biotype may be in the process of becoming the dominant biotype. In a similar study, Chu et al. (2010) reported the presence of the Q (MED) biotype in the Shandong District of China: the B biotype was the dominant biotype until 2005, but the Q biotype became the dominant biotype within three years. Similar data were reported for populations in Spain; after introduction of the B biotype in the country, the Q biotype regained its dominance over the B biotype for a period of time (Brown et al., 2000; Simón et al., 2007). In another study, the Q biotype was reported to have become dominant in many regions of China partly by occupying the $\mathrm{B}$ biotype regions (Teng et al., 2010).

In the present study, whitefly populations collected on vegetables and cotton from Antalya province between 2005 and 2006 were identified as the B and Q biotypes. Both the B and Q biotypes were found in Antalya in 2005 (Topakçı and Göçmen, 2018). However, Erdoğan et al. (2011) reported that only the B biotype was collected from tomatoes and eggplants in Antalya province during the 2007-2009 period. Similarly, only the B biotype was reported from different districts of Antalya province in 2011 (Yükselbaba and Göçmen, 2012).

The populations collected from Aydin and Denizli provinces (Qw) were clustered within the same subgroup showed one-to-one similarity to the Greece Q biotype, and the populations collected from Adana, Hatay and Antalya provinces (Qe) were clustered within the same subgroup with the Syria and Cyprus samples. Similar findings were reported about the species and subgroups of $B$. tabaci populations collected from southwestern cotton fields in 2015 (Karut et al., 2017). In one study, the Q biotypes clustered into two subgroups under the Mediterranean main group (Dinsdale et al., 2010). The population from Turkey used by Dinsdale et al. (2010), was found to have the same evolutionary relationship with the Qe biotypes used in this study. It was observed that the samples collected from Spain, Greece and other European countries were clustered into the same subgroup of the Mediterranean main group, hence, our data are in agreement with the above-mentioned information after clarification of the $\mathrm{Q}$ biotype into Qe and Qw haplotypes.

The intra-population variations in all the three biotypes found in Turkey are at the zero level in terms of mtCOI. For this reason, predicting which of these populations appeared earlier in our country is impossible. However, a collected and known sample was established to show a close relationship to the $\mathrm{Q}$ biotype; this sample is regarded as the oldest record for our country. Based on the literature, the B biotype was first 
described between 1988 and 1989 in the USA, whereas the Q biotype was first described in Spain in 1997. However, the origin of both biotypes is known to be the Mediterranean. For this reason, the likelihood of the B biotype existing in our country before 1985 is at least as high as that of the Q biotype. Answering this question will only be possible if more variations of each biotype are investigated and revealed. For this goal, investigating these biotypes with different fingerprinting methods is a useful approach. When geographically distributed biotypes are examined, the transition zone between the $\mathrm{B}$ and $\mathrm{Q}$ biotypes will probably be the transition zone between Tarsus and Mersin from Q to B, whereas Central Antalya is likely to be a re-transition zone from $\mathrm{B}$ to $\mathrm{Q}$.

\section{Conclusion}

Studies needs to be conducted in these regions to provide detailed information about gene exchange between the biotypes or the evolution of the biotypes into dominant species in different geographic regions. In addition, testing whitefly samples taken at regular intervals every year will be useful for monitoring how the biotypes are distributed in our southern regions, where agriculture is heavily concentrated.

Acknowledgements. We thank the TÜBITAK for their contribution to the TOVAG-104O312 project.

Conflict of interests. The authors declare that they have no conflict of interests.

\section{REFERENCES}

[1] Abdullahi, I., Winter, S., Atiri, G. I., Thottappilly, G. (2003): Molecular characterization of whitefly, Bemisia tabaci (Hemiptera: Aleyrodidae) populations infesting cassava. Bulletin of Entomological Research 93(2): 97-106.

[2] Bayhan, E., Ulusoy, M., Brown, J. K. (2006): Host range, distribution and natural enemies of Bemisia tabaci B biotype (Homoptera:Aleyrodidae) in Turkey. - Journal of Pest Science 79: 233-240.

[3] Bedford, I. D., Briddon, R. W., Brown, J. K., Rosell, R., Markham, P. G. (1994): Geminivirus transmission and biological characterisation of Bemisia tabaci (Gennadius) biotypes from different geographic regions. - Annals of Applied Biology 125: 311-325.

[4] Boykin, L. M., De Barro, P. J. (2014): A practical guide to identifying members of the Bemisia tabaci species complex: and other morphologically identical species. - Frontiers in Ecology and Evolution 2(45) doi.org/10.3389/fevo.2014.00045.

[5] Boykin, L. M., Savill, A., De Barro, P. (2017): Updated mtCOI reference dataset for the Bemisia tabaci species complex F1000. - Research 6: 1835 (DOI: 10.12688/f1000research.12858.1).

[6] Brown, J. K. (2000): Molecular markers for the identification and global tracking of whitefly vector-Begomovirus complexes. - Virus Res. 71(1-2): 233-260.

[7] Brown, J. K., Coats, S. A., Bedford, I. D., Marcham, P. G., Bird, J., Frohlich, D. R. (1995): Characterization and distribution of esterase electromorphs in the whitefly, Bemisia tabaci (Genn.) (Homoptera:Aleyrodidae). - Biochemical Genetics 33(7/8): 205214.

[8] Cervera, M. T., Cabezas, J. A., Simón, B., Martinez-Zapater, J. M., Beitia, F., Cenis, J. L. (2000): Genetic relationships among biotypes of Bemisia tabaci (Hemiptera:Aleyrodidae) based on AFLP analysis. - Bulletin of Entomological Research 90: 391-396. 
[9] Chu, D., Wan, F. H., Zhang, Y. J., Brown, J. K. (2010): Change in the biotype composition of Bemisia tabaci in Shandong Province of China from 2005 to 2008. Environmental Entomology 39: 1028-1036.

[10] Costa, H. S., Brown, J. K. (1991): Variation in biological characteristics and esterase patterns among populations of Bemisia tabaci and the association of one population with silverleaf symptom induction. - Entomologia Experimentalis et Applicata 61: 211-219.

[11] De Barro, P. J. (2005): Genetic structure of the whitefly Bemisia tabaci in the AsiaPasific region revealed using microsatellite markers. - Molecular Ecology 14: 3695-3718.

[12] De Barro, P. J., Driver, F., Trueman, J. W. H., Curran, J. (2000): Phylogenetic relationships of world populations of Bemisia tabaci (Gennadius) using ribosomal ITS1. - Molecular Phylogenetics and Evolution 16(1): 29-36.

[13] De Barro, P. J., Liu, S. S., Boykin, L. M., Dinsdale, A. B. (2011): Bemisia tabaci: a statement of species status. - Annual Review of Entomology 56: 1-19.

[14] Dinsdale, A., Cook, L., Riginos, C., Buckley, Y. M., De Barro, P. (2010): Refined global analysis of Bemisia tabaci (Hemiptera: Sternorrhyncha: Aleyrodoidea: Aleyrodidae) mitochondrial cytochrome oxidase 1 to identify species level genetic boundaries. Annals of the Entomological Society of America 103(2): 196-208.

[15] Erdoğan, C., Velioğlu, A. S., Gürkan, M. O., Moores, G. D., Denholm, I. (2011): Determination of Trialeurodes vaporariorum (Westw.) and Bemisia tabaci (Genn.) (Hemiptera:Aleyrodidae) species collected from greenhouses by using polyacrylamide gel electrophoresis. - Bitki Koruma Bülteni 51(4): 373-385 (in Turkish with English abstract).

[16] Frohlich, D. R., Torres-Jerez, I., Bedford, I. D., Markham, P. G., Brown, J. K. (1999): A phylogeographical analysis of the Bemisia tabaci species complex based on mitochondrial DNA markers. - Molecular Ecology 8: 1683-1691.

[17] Gawell, N. J., Barlett, A. C. (1993): Characterization of differences between whiteflies using RAPD-PCR. - Insect Molecular Biology 2(1): 33-38.

[18] Göçmen, H., Devran, Z. (2002): Determination of genetic variation in populations of Bemisia tabaci in Antalya. - Turkish Journal of Agriculture and Forestry 26: 211-216.

[19] Göçmen, H., Özgür, A. F. (1990): Migration of cotton whitefly Bemisia tabaci (Genn.) (Homoptera:Aleyrodidae) between various host plants and its population changes (in Turkish). - Çukurova University, Institute of Natural and Applied Science, Journal of Science and Engineering 4(3): 115-129.

[20] Göçmen, H., İkten, C., Göçmen, M., Devran, Z., Topakç1, N. (2004): The research on genetic variations of cotton white fly Bemisia tabaci (Genn.) (Homoptera; Aleyrodidae). - Proceedings of the First Plant Protection Congress of Turkey, 8-10 September 2004, Samsun, Turkey.

[21] Guirao, P., Beitia, F., Cenis, J. L. (1997): Biotype determination of Spanish populations of Bemisia tabaci (Hemiptera:Aleyrodidae). - Bulletin of Entomological Research 87: 587-593.

[22] Horowitz, A. R., Denholm, I., Gorman, K., Cenis, J. L., Kontsedalov, S., Ishaaya, I. (2003): Biotype Q of Bemisia tabaci identified in Israel. - Phytoparasitica 31(1): 1-5.

[23] Karut, K., Malik, A. A. Y., Kazak, C., Kamberoğlu, M. A., Ulusoy, M. R. (2012): Determination of biotypes of Bemisia tabaci Gennadius 1889 (Hemiptera: Aleyrodidae) on different host plant in Adana (Balcalı) by using two different molecular methods. Turkish Journal of Entomology 36: 93-100 (in Turkish with English abstract).

[24] Karut, K., Kaydan, M. B., Castle, S. J., Kazak, C., Ulusoy, M. R. (2014): Study on species composition of Bemisia tabaci (Gennadius, 1889) (Hemiptera: Aleyrodidae) on cotton in Çukurova plain, Turkey. - Turkish Journal of Entomology 38(1): 43-50.

[25] Karut, K., Karaca, M. M., Döker, İ., Kazak, C. (2017): Analysis of Species, Subgroups, and Endosymbionts of Bemisia tabaci (Hemiptera: Aleyrodidae) From Southwestern Cotton Fields in Turkey. - Environmental Entomology. DOI: 10.1093/ee/nvx093. 
[26] Kumar, S., Stecher, G., Li, M., Knyaz, C., Tamura, K. (2018): MEGA X: Molecular Evolutionary Genetics Analysis across computing platforms. - Molecular Biology and Evolution 35: 1547-1549.

[27] Lima, L. H. C., Campos, L., Moretzsohn, M. C., Navia, D., De Oliveira, M. R. V. (2002): Genetic diversity of Bemisia tabaci (Genn.) populations in Brazil revealed by RAPD markers. - Genetic and Molecular Biology 25(2): 217-223.

[28] Moya, A., Guirao, P., Cifuentes, D., Beitias, F., Cenis, J. L. (2001): Genetic diversity of Iberian populations of Bemisia tabaci (Hemiptera:Aleyrodidae) based on RAPD- PCR. Molecular Ecology 10: 891-897.

[29] Simón, B., Moriones, E., Soria, C., Beitia, F., Bosco, D., Cenis, J. L. (1999): Variación genética de poblaciones de Bemisia tabaci (Gennadius) en la cuenca del Mediterráneo occidental. - Proc. Congreso Nacional de Entomología Aplicada. Aguadulce, Spain, Nov 8-12.

[30] Simón, B., Cenis, J. L., De La Rúa, P. (2007): Distribution patterns of the Q and B biotypes of Bemisia tabaci in the Mediterranean Basin based on microsatellite variation. - Entomologia Experimentalis et Applicata 124(3): 327-336.

[31] Teng, X., Wan, F. H., Chu, D. (2010): Bemisia tabaci biotype Q dominates other biotypes across China. - Florida Entomologist 93(3): 363-368.

[32] Topakç1, N., Göçmen, H. (2018): A research on the determination of molecular genetic characteristics of some Bemisia tabaci (Genn.) (Hemiptera:Aleyrodidae) populations. Fresenius Environmental Bulletin 2: 1095-1103.

[33] Ulusoy, R., Brown, J. K., Bayhan, E. (2002): The B biotype of Bemisia tabaci now established in European whitefly studies. - Network Newsletter 13(5): 4.

[34] Valle, G. E., Lourenção, A. L., Zucchi, M. I., Pinheiro, J. B., De Abreu, A. G. (2013): Population variability of Bemisia tabaci (Genn.) in different hosts. - Genetics and Molecular Research 12(4): 4615-4624.

[35] Yükselbaba, U., İkten, C., Göçmen, H. (2012): Determination of the biotypes of Bemisia tabaci (Gennadius) (Hemiptera: Aleyrodidae) populations from Antalya Province of Turkey by sequence analysis of mitochondrial cytochrome oxidase I (mtCOI) gene region. - QBOL-EPPO Conf-DNA Barcoding and Diagnostic Methods for Plant Pests, 21-25 May, Haarlem, Holland. 